\title{
Indonesia Dijajah Lebih dari 300 Tahun? Menjelaskan Penjajahan sebagai Proses Transformasi Struktural
}

\author{
Shofwan Al Banna Choiruzzad ${ }^{1}$ \\ ${ }^{1}$ Departemen Ilmu Hubungan Internasional, FISIP, Universitas Indonesia, Indonesia
}

\section{SUBMISSION TRACK}

$\begin{array}{ll}\text { Received } & : 02 \text { December2020 } \\ \text { Final Revision } & : 18 \text { March } 2021 \\ \text { Available Online } & : 01 \text { May } 2021\end{array}$

\section{KEYWORD}

Indonesia, colonialism, imperialism, historical myths, historical facts, interpretation of history, International Political Economy

\section{KATA KUNCI}

Indonesia, penjajahan, kolonialisme, imperialisme, mitos sejarah, fakta sejarah, interpretasi sejarah, Ekonomi Politik Internasional

\section{CORRESPONDENCE}

$\begin{array}{ll}\text { Phone } & :+6281293459485 \\ \text { E-mail } & : \underline{\text { shofwan.albanna@ui.ac.id }} \\ & \text { shofwan.albanna@gmail.com }\end{array}$

\section{A B S T R A C T}

Despite its public popularity, the claim that Indonesia was colonized by the Dutch for more than 300 years is now considered by historians as a historical myth, established as an instrument for nation-building. This article argues that rather than simply judging the claim as myth, we must understand it more comprehensively by employing the framework of International Political Economy, especially the approach which put the entanglements of Capitalism and Colonialism at the center of its analysis. To do so, this paper attempts to understand the texts written by Indonesian nationalist thinkers on this issue by looking at their approach and the context that shape the argument that Indonesia was colonized for more than 300 years. Through that reading, this paper identifies two important elements upon which the argument was built: (1) Colonialism-Imperialism as structural transformation and not merely formal political control; and (2) ColonialismImperialism is a process and not an event. By understanding Colonialism-Imperialism as a process of structural transformation, this article contends that the claim that Indonesia had been colonized by the Dutch for more than 300 years has its own merit and must be further explored..

\section{A B S T R A K}

Meskipun populer, pernyataan bahwa Indonesia dijajah oleh Belanda selama lebih dari 300 tahun sekarang dianggap oleh para sejarawan sebagai mitos historis yang dibuat sebagai instrumen pembangunan kebangsaan. Artikel ini berangkat dari pandangan bahwa kita harus melampaui penghakiman terhadap klaim tersebut dan memahaminya secara lebih komprehensif dengan menggunakan kerangka Ekonomi Politik Internasional, khususnya dengan pendekatan yang meletakkan pertautan antara Kapitalisme dan Kolonialisme di pusat analisisnya. Untuk melakukan hal tersebut, tulisan ini memahami pemikiran kaum nasionalis Indonesia pada awal Abad 20 dengan menelusuri pendekatan yang mereka gunakan dan konteks argumen yang mereka ajukan bahwa Indonesia telah dijajah lebih dari 300 tahun. Melalui pembacaan tersebut, tulisan ini menemukan bahwa ada dua elemen dasar yang menopang argumen tersebut: (1) Mereka memahami penjajahan sebagai transformasi struktural, bukan semata penguasaan politik formal; dan (2) Mereka memahami penjajahan sebagai proses, bukan sekedar peristiwa (event). Dengan memahami penjajahan sebagai sebuah proses transformasi struktural, artikel ini berpendapat bahwa klaim yang menyebutkan bahwa Indonesia dijajah selama lebih dari 300 tahun memiliki sisi kebenarannya sendiri dan dengan demikian perlu terus didiskusikan lebih lanjut. 


\section{Pendahuluan}

"Telah 300 tahoen lebih lamanja bangsa kita kehilangan kemerdekaan, dan 300 tahoen lebih poela tanah kita terdjadjah oleh bangsa asing. Didalam waktoe jang selama itoe telah amat banjak jang kita rasai, dan telah tjoekoeplah kepedihan dan kesakitan jang menerkam diri kita, hingga hampir habis rasanja kekoeatan toelang sendi kita boeat hidoep sebagai manoesia jang noermal. Demikianlah nasib anak djadjahan, dimana negeri dan tempat djaranglah jang boleh dikatakan baik dan sederhana hidoepnja, kemana-mana malanglah nasibnja, makin lama negerinja djadi tanah djadjahan, makin kelihatanlah toelang poenggoengnja, makin poetjat roman moekanja dan makin melarat penghidoepannja: karena ra'jat djadjahan itoe tergantoeng semata-mata pada kekoeasaan fihak jang mendjadjah, jang kehendak, kemaoean dan kepentingannja ada berlawanan belaka dengan kemaoean, kehendak dan kepentingan Ra'jat jang didjadjahnja!"

("Koloniaal Onderwijsstelsel dan Nasibnja Anak Djadjahan”, Fikiran Ra'jat, 16 Desember 1932) ${ }^{1}$

Argumen utama dari tulisan ini adalah bahwa para aktivis pergerakan nasional seperti Soekarno atau Hatta tidak sekedar bermain retorika dan membangun mitos kebangsaan ketika mereka bertutur tentang penjajahan Belanda selama lebih dari 300 tahun. Hal ini juga bukan berarti argumen para sejarawan seperti G.J. Resink yang melihat dari pendekatan hukum bahwa Kerajaan Belanda hanya menguasai Indonesia sejak awal abad 19 dan tidak meliputi seluruh wilayah Indonesia itu salah. $^{2}$

Hanya saja, klaim Soekarno atau Hatta ini harus diletakkan dalam konteks yang tepat. Klaim tersebut lebih tepat dinilai dari pendekatan yang sama yang digunakan oleh Soekarno atau Hatta, bukan dengan menggunakan pendekatan sejarah hukum yang berfokus pada dokumen formal. Soekarno dan Hatta adalah aktivis dan

\footnotetext{
1 Fikiran Ra'jat adalah majalah politik mingguan populer yang dipimpin oleh Soekarno yang terbit sejak Juli 1932 hingga tahun 1933.

2 Gertrudes Johannes Resink, Bukan 350 Tahun Dijajah (Depok: Komunitas Bambu, 2013).
}

intelektual yang membaca dan menulis mengenai penjajahan dengan berfokus pada pertautan antara kolonialisme dengan kapitalisme. ${ }^{3}$ Dengan demikian, lebih adil jika kita menilai klaim tersebut tidak menggunakan pendekatan sejarah hukum saja, namun menggunakan pendekatan yang dimaksudkan dalam menganalisis penjajahan tersebut oleh Soekarno dan Hatta, yaitu dengan berfokus pada relasi antara kolonialisme dengan kapitalisme. Walaupun tidak pernah mengidentifikasi diri demikian, Soekarno dan Hatta adalah pengkaji Ekonomi Politik Internasional, dan karena itu argumennya harus didekati sebagai analisis Ekonomi Politik Internasional, bukan hukum atau sejarah hukum.

Tulisan ini mencoba memahami dan memperluas argumen bahwa "Indonesia dijajah lebih dari 300 tahun" dengan menggunakan pendekatan Ekonomi Politik Internasional, khususnya pemahaman para pengkaji Ekonomi Politik Internasional yang meletakkan relasi kolonial sebagai proses yang melandasi dan sekaligus tumbuh bersama ekspansi pasar dan/atau perubahan relasi sosial dari sistem produksi kapitalis, yang selaras dengan cara berpikir Soekarno dan Hatta dalam melihat penjajahan. ${ }^{4}$

\section{Metode Penelitian}

Untuk mencapai tujuan tersebut, penelitian ini menggunakan metode kualitatif yang berangkat dari posisi epistemologis interpretif dan posisi ontologis konstruksionis. ${ }^{5}$ Interpretif berarti bahwa dunia sosial harus dipahami melalui

3 Soekarno, Di Bawah Bendera Revolusi (Jilid Pertama), Cetakan Ke (Jakarta: Yayasan Bung Karno, 2005); Mohammad Hatta, Kumpulan Karangan (Jakarta, Amsterdam, Surabaya: Penerbitan dan Balai Buku Indonesia, 1953); Mohammad Hatta, Mohammad Hatta: Politik, Kebangsaan, Ekonomi (1926-1977) (Jakarta: Penerbit Buku Kompas, 2015).

4 Soekarno, Di Bawah Bendera Revolusi (Jilid Pertama); Hatta, Mohammad Hatta: Politik, Kebangsaan, Ekonomi (1926-1977).

${ }^{5}$ Alan Bryman, Social Research Methods, 4th edition (Oxford: Oxford University Press, 2012), 380-84. 
pemahaman terhadap interpretasi mengenai realitas tersebut oleh partisipan/subyek yang dikaji dan bukan melalui model obyektif. Konstruksionis berarti bahwa properti sosial adalah hasil dari interaksi antara individuindividu dalam relasi sosial dan bukan "fenomena obyektif" yang terpisah dari individu-individu yang terlibat dalam relasi sosial. ${ }^{6}$ Posisi epistemologis dan ontologis ini menjadi titik tolak penting bagi penelitian ini, yang melihat bahwa perdebatan mana yang benar antara apakah Indonesia dijajah lebih dari 300 tahun atau tidak seharusnya bukan didekati sebagai perdebatan benarsalah, karena keduanya bisa jadi benar, jika kita menggunakan kerangka interpretasi yang berbeda. Lebih jauh lagi, kerangka interpretasi yang lebih tepat untuk menilai klaim dari para founding fathers Republik Indonesia seperti Soekarno dan Hatta, dengan demikian, adalah dengan pendekatan yang mempertimbangkan pendekatan yang mereka gunakan dan konteks personal mereka sebagai aktivis dan pemikir yang melihat dalam kerangka yang khas. Hal ini selaras dengan penekanan dari Audie Klotz bahwa konteks dan interpretasi adalah ciri utama dari penelitian kualitatif dalam kajian Hubungan Internasional. ${ }^{7}$

Tentu saja, tulisan ini tidak hendak membantah karya besar G.J. Resink atau interpretasi dari para sejarawan Indonesia seperti A.B. Lapian. Namun, penulis berpandangan bahwa untuk memahami esensi dari klaim bahwa "Indonesia dijajah Belanda lebih dari 300 tahun" oleh para founding fathers seperti Soekarno dan Hatta, kita perlu mendekatinya dengan perspektif berbeda. Sebagaimana kita ketahui, baik Soekarno dan Hatta bukanlah sejarawan, meskipun sangat fasih menuturkan sejarah. Keduanya memaknai sejarah lebih sebagai seorang pengkaji Ekonomi Politik atau Ekonomi Politik Internasional, yang

\footnotetext{
${ }^{6}$ Bryman, 380.

${ }^{7}$ Audie Klotz dan Deepa Prakash (Eds.), Qualitative Methods in International Relations: A Pluralist Guide (Hampshire and New York: Palgrave McMillan, 2008).
}

meletakkan sejarah sebagai rangkaian puzzle yang kemudian dimaknai untuk memahami perkembangan relasi antara kelompok masyarakat (bisa berbasis kelas, ras, atau identitas kolektif lainnya). Secara khusus, sebagai pemikir anti-kolonial, tokoh-tokoh ini mencoba memahami posisi Indonesia dalam sejarah perkembangan kolonialismeimperialisme dan kapitalisme yang bertautan erat. Benang merah ini terlihat dalam karyakarya Soekarno (yang dalam Indonesia Menggugat menjelaskan perbedaan Kolonialisme Tua dan Kolonialisme Modern) dan Hatta (yang berpidato di pembukaan masa kepemimpinan Perhimpunan Indonesia pada 1926 dengan berbicara tentang "Struktur Ekonomi Dunia dan Konflik Kekuasaan"). ${ }^{8}$

Dengan titik berangkat yang demikian, kita dapat melihat secara lebih adil bahwa Soekarno, Hatta, atau tokoh-tokoh pendiri bangsa Indonesia tidak sedang melakukan manipulasi (meskipun niatnya baik). Mereka tidak sedang melanggengkan mitos Pax Nederlandica. Mereka tidak hanya menggunakan klaim tersebut secara instrumental (untuk membangun nasionalisme) sehingga mengabaikan kebenaran faktual dari klaim tersebut. Dengan menggunakan persepektif Ekonomi Politik Internasional yang khas, yang meletakkan perkembangan dan pertautan kolonialisme dan kapitalisme sebagai pusat analisis (yang sebenarnya sudah dikembangkan oleh Soekarno dan Hatta namun tidak tuntas karena keterlibatan mereka sebagai aktivis politik), kita dapat memahami bahwa pemahaman bahwa Indonesia dijajah oleh Belanda selama lebih dari 300 tahun tersebut memiliki sisi kebenarannya sendiri.

Untuk memahami hal ini, penting untuk menilik definisi "penjajahan" itu sendiri. Dengan penelitian yang rinci oleh Resink mengenai beragam perjanjian antara

\footnotetext{
8 Soekarno, Di Bawah Bendera Revolusi (Jilid Pertama); Hatta, Mohammad Hatta: Politik, Kebangsaan, Ekonomi (1926-1977).
} 
Belanda dengan berbagai pihak di lingkungan Hindia-Belanda, tentu saja kita tidak bisa membantah bahwa secara legal masih ada entitas yang secara formal diakui oleh Belanda memiliki kedaulatan di wilayah yang kemudian disebut sebagai HindiaBelanda. Namun, di sinilah interpretasi mengenai apa itu penjajahan menjadi penting. Tulisan ini bertujuan untuk memberikan interpretasi Ekonomi Politik Internasional, yang menurut penulis lebih konsisten dengan cara berpikir Soekarno dan Hatta, mengenai penjajahan Belanda terhadap Indonesia.

Interpretasi tersebut dilakukan dengan mengidentifikasi elemen-elemen utama dari argumen bahwa "Indonesia dijajah lebih dari 300 tahun" dengan mencari kongruensinya dengan perkembangan kajian Ekonomi Politik Internasional.

Tulisan ini disusun ke dalam sistematika sebagai berikut: setelah menjelaskan latar belakang dan rumusan masalah, tulisan ini menjelaskan metode penelitian yang digunakan. Setelah itu, selaras dengan pendekatan yang digunakan, tulisan ini melanjutkan dengan bagian pembahasan dan analisis, yang terdiri dari beberapa sub-bagian. Bagian ini dimulai dengan membahas kesalahpahaman paradigmatik yang membuat kita terburuburu menghakimi klaim "Indonesia dijajah lebih dari 300 tahun" tersebut. Sub-bagiansub-bagian selanjutnya merupakan upaya untuk membangun penjelasan yang lebih sistematis dengan menggunakan pendekatan Ekonomi Politik Internasional, dengan mengidentifikasi dua elemen utama: (1) Definisi penjajahan sebagai transformasi struktural dan (2) Penjajahan sebagai proses. Analisis dimulai dengan memahami definisi "penjajahan." Bagian selanjutnya mendiskusikan durasi penjajahan tersebut dan menunjukkan mengapa klaim bahwa Indonesia dijajah Belanda selama lebih dari 300 tahun memiliki sisi kebenarannya sendiri dengan menginterpretasikan penjajahan sebagai proses, bukan sekedar "event". Terakhir, tulisan ini ditutup dengan kesimpulan.

\section{Pembahasan dan Analisis}

\section{Kesalahpahaman Paradigmatik: Perbedaan dalam Memahami Penjajahan Belanda Lebih dari 300 Tahun}

Sebagai sebuah negara yang lahir sebagai perlawanan dari penjajahan, sebagaimana ditunjukkan dalam pembukaan UUD 1945 ("Bahwa sesungguhnya Kemerdekaan itu ialah hak segala bangsa dan oleh sebab itu, maka penjajahan di atas dunia harus dihapuskan, karena tidak sesuai dengan perikemanusiaan dan perikeadilan"), pembangunan identitas nasional Indonesia tidak terlepas dari interpretasi elit nasional terhadap sejarah penjajahan itu sendiri. Pada masa kebangkitan nasional, para nasionalis seperti Soekarno dan Hatta menyalakan semangat kemerdekaan dengan menyebutkan bahwa Indonesia telah dijajah lebih dari 300 tahun. Hal ini bertautan dengan klaim dari pemerintah kolonial Belanda sendiri, seperti Gubernur Jenderal de Jonge yang masyhur dengan pernyataannya yang berbunyi: "Kami telah memerintah di sini selama tiga ratus tahun dengan cambuk dan tongkat dan kami harus tetap melakukannya untuk tiga ratus tahun lagi". 9

Persepsi para elit pergerakan nasional dan musuhnya, penguasa kolonial Belanda, mengenai durasi penjajahan yang panjang itu kemudian ditopang oleh populernya ramalan yang disebut-sebut berasal dari Jayabaya. Pada tanggal 1 Mei 1912, Raden Nitipraja menerbitkan sebuah tulisan di Het Tijdschrift yang di dalamnya mengandung ramalan mengenai berakhirnya penjajahan Belanda di tangan penjajah berkulit kuning. Kontras dengan penjajahan Belanda yang ratusan tahun, penjajahan bangsa kulit kuning itu hanya akan berusia pendek. Muhammad Husni Thamrin, tokoh Betawi yang memilih berjuang di dalam Volksraad, menceritakan

\footnotetext{
9 Tyson Tirta, "Bagaimana G.J. Resink Membongkar Mitos 350 Tahun Penjajahan Belanda," Tirto, 2020, https://tirto.id/bagaimana-gj-resink-membongkarmitos-350-tahun-penjajahan-belanda-f3sv.
} 
isi dari ramalan itu pada sidang Dewan tersebut pada bulan Juli 1934: "Kalau negara Jawa tinggal sebesar daun kelor, nanti ia akan dijajah oleh orang Tionghoa (Thamrin menafsirkan: “Jepang?"). Namun lamanya hanya seumur jagung. Setelah itu, akan kembali ke tangan orang Jawa kembali. Jika teratai putih telah sirna, maka datanglah waktu yang sentosa/merdeka untuk sekalian orang Jawa itu". ${ }^{10}$

Setelah Indonesia merdeka, persepsi mengenai durasi penjajahan Belanda yang disebut-sebut berusia lebih dari 300 tahun (sebagian membulatkannya menjadi 350 tahun) tersebut mulai ditinjau kembali, seiring dengan kemunculan generasi pertama sejarawan Indonesia yang mengkaji sejarah Indonesia dengan lebih sistematis. Gertrudes Johannes Resink, seorang sejarawan berdarah Belanda yang lahir di Yogyakarta kemudian memilih menjadi warga negara Indonesia, mengajukan klaim kuat bahwa klaim kekuasaan Belanda atas Hindia Belanda selama 350 tahun tersebut hanyalah mitos belaka. Berdasarkan penelitiannya terhadap arsip-arsip perjanjian antara VOC dan Belanda dengan berbagai pihak di wilayah yang kemudian menjadi Indonesia, ia berpendapat bahwa sampai awal abad 20, ada berbagai wilayah di Hindia Belanda yang diakui oleh Belanda sebagai memiliki kedaulatannya sendiri. ${ }^{11}$ Sejak saat itu, kalangan sejarawan secara umum melihat bahwa cerita mengenai "Indonesia dijajah Belanda lebih dari 300 tahun" hanyalah mitos belaka. Sebagian bahkan menyebutnya sebagai "manipulasi sejarah." Sebagian lagi berpendapat bahwa pemahaman yang dipopulerkan oleh para politisi Indonesia seperti Soekarno tersebut memiliki makna positif, yaitu "membangkitkan semangat nasionalisme dan patriotisme bangsa Indonesia, serta legitimasi persatuan dan kesatuan bangsa Indonesia" namun tetap saja

10 Anhar Gonggong, Muhammad Husni Thamrin (Jakarta: Departemen Pendidikan dan Kebudayaan, 1985), 66.

${ }^{11}$ Resink, Bukan 350 Tahun Dijajah. "bukan fakta sejarah". ${ }^{12}$ Meskipun demikian, pemahaman bahwa Belanda pernah menjajah Indonesia selama 350 tahun tetaplah populer di kalangan masyarakat.

Berangkat dari kesenjangan antara pandangan yang populer di masyarakat dan upaya "pelurusan" yang dilakukan oleh sejarawan, penulis merasa bahwa sebenarnya kedua hal tersebut bukan hal yang kontradiktif. Keduanya melihat dengan ukuran yang berbeda. Para sejarawan dan ahli sejarah hukum melihat dari kacamata legal formal, sementara pandangan yang populer di masyarakat menunjukkan pengaruh pemikiran Soekarno dan Hatta yang masih bertahan hingga hari ini karena kekuatan analisisnya.

Dengan demikian, kita dapat melihat bahwa popularitas pemahaman tersebut tidak hanya dapat dijelaskan melalui posisinya sebagai bagian penting dari proyek pembangunan nasionalisme Indonesia yang dimulai sejak masa kebangkitan nasional, namun karena memang ada interpretasi yang dapat menopang pemahaman tersebut, meskipun tidak tepat dalam angka 350 tahun. Namun, perlu ada upaya yang lebih sistematis untuk mengurai argumen tersebut dalam kerangka Ekonomi Politik Internasional.

\section{Tahun Penjajahan: Interpretasi Ekonomi Politik Internasional}

Dalam tulisannya yang berjudul "Pengaruh Koloniaal Kapitaal di Indonesia," Mohammad Hatta menuliskan bahwa: "Maksud Nederland menguasai Indonesia tidak lain melainkan untuk memungut hasil. Dahulu pekerjaan ini didjalankan oleh OostIndische Compagnie, kemudian oleh pemerintah sendiri dengan djalan Cultuurstelsel dan achirnja oleh kaum

\footnotetext{
${ }^{12}$ Ulil Absiroh, "Understanding of History 350 Years Indonesia Colonized By Dutch," Jurnal Online Mahasiswa (JOM) Fakultas Keguruan Dan Ilmu Pendidikan (FKIP) Universitas Riau 1 (2017): 1-15, https://www.neliti.com/publications/205480/sejarahpemahaman-350-tahun-indonesia-dijajah-belanda.
} 
Shofwan Al Banna Choiruzzad | Indonesia Dijajah Lebih dari 300 Tahun?

Memahami Penjajahan sebagai Proses Transformasi Struktural

kapitalis partikulir menurut tanggungan sendiri, sedangkan sekarang pemerintah Hindia Belanda mendjadi pendjaganja sadja". ${ }^{13}$

Dari tulisan tersebut, terlihat jelas bahwa Hatta bukannya tidak mengerti bahwa pemerintah Belanda baru menguasai resmi wilayah Hindia Belanda setelah VOC bangkrut. Namun, ia tetap menghitung era VOC sebagai satu kesatuan yang berlanjut dengan keseluruhan cerita penjajahan Belanda. Mengapa? Karena Hatta tidak hanya melihat status legal formal saja tentang siapa yang berkuasa, tapi melihat struktur relasi yang terbentuk dan berlanjut.

Bahkan, menarik untuk melihat bahwa Hatta membedakan dua periode dalam masa pemerintahan kolonial Belanda yang secara legal formal berada dalam sistem pemerintahan kolonial yang sama: masa cultuurstelsel (ketika negara menjadi aktor dominan dalam tata kelola ekonomi politik di Hindia Belanda) dan pasca-penghapusan tanam paksa yang berkaitan dengan Revolusi Liberal di Eropa (ketika negara mengurangi perannya dalam perekonomian dan membiarkan swasta Eropa mendominasi).

Pandangan yang sama juga terlihat dalam berbagai tulisan di Fikiran Ra'jat, media yang menjadi corong bagi gagasangagasan Soekarno yang terbit pekanan pada tahun 1932-1933. Dalam salah satu artikel yang secara eksplisit menulis tentang "300 tahun penjajahan," yang terbit pada 16 Desember 1932, penjajahan juga tidak dimaknai secara legal formal, tetapi struktural. Artikel tersebut memahami dengan jelas bahwa VOC dan pemerintah kolonial Belanda itu berbeda secara formal, namun sebenarnya merupakan sebuah koloniaal onderwijstelsel yang berkelanjutan. "Sekarang njatalah semoea perdjalanan Onderwijstelsel yang menjadi pendoman ialah kepentingan mereka belaka". ${ }^{14}$

\footnotetext{
${ }^{13}$ Hatta, Kumpulan Karangan, 244.

14 "Koloniaal Onderwijsstelsel Dan Nasibnja Anak Djadjahan," Fikiran Ra'jat, December 1932.
}

Dengan demikian, untuk memberikan pemahaman sistematis mengenai klaim bahwa Indonesia telah dijajah lebih dari 300 tahun, kita harus mulai dari bagaimana mendefinisikan penjajahan. Penjajahan adalah sebuah proses transformasi struktural.

\section{Penjajahan Sebagai Proses Transformasi Struktural}

Meski sering digunakan, tidak ada kesepakatan penuh tentang definisi istilah Kolonialisme, Imperialisme, maupun perbedaan dan hubungan di antara keduanya. Dalam kenangan kolektif bangsa kita yang ditanamkan melalui berbagai proyek pembangunan kebangsaan, kita sering memahami kolonialisme dan imperialisme sebagai hal yang sama. Kita mengenali keduanya dalam satu tarikan nafas: Penjajahan. Kamus Besar Bahasa Indonesia menjelaskan penjajahan sebagai "proses, cara, perbuatan menjajah." Menjajah sendiri diartikan oleh KBBI sebagai "menguasai dan memerintah suatu negeri." Meskipun definisi tersebut sangat umum, pengertian tersebut merupakan jantung dari semua definisi yang beragam mengenai Kolonialisme dan Imperialisme: "Penguasaan terhadap masyarakat atau negeri yang asing." Atau, jika dilihat dari perspektif pihak yang dijajah: "penguasaan asing terhadap suatu masyarakat atau negara."

Secara etimologis, "Kolonialisme" berasal dari kata dalam Bahasa Latin "Colere," bahasa yang digunakan oleh Kekaisaran Romawi, yang berarti menempati, bertani, atau mengolah tanah. ${ }^{15}$ Konotasi agrikultur ini sangat berkaitan dengan ekspansi Romawi yang diikuti dengan pengiriman penduduk untuk membuka wilayah-wilayah baru tersebut. Dari "Colere," muncullah kata "Colonus," yang

15 George Steinmetz, "The Sociology of Empires, Colonies, and Postcolonialism," Annual Review of Sociology 40, no. 1 (2014): 79, https://doi.org/10.1146/annurev-soc-071913-043131. 
berarti petani. ${ }^{16}$ Dari kata ini muncullah kata "koloni" yang dimaknai sebagai "wilayah yang ditempati oleh emigran yang berasal dari negara asalnya". ${ }^{17}$ Sementara itu, "Imperialisme" dapat dirunut asalnya dari kata "imperium" yang bermakna "memerintah". 18

Dengan asal kata yang demikian, tidak mengherankan bahwa sebagian ilmuwan mendefinisikan dan membedakan Kolonialisme dan imperialisme berdasarkan keberadaan pemukim yang berasal dari negara asal yang menguasai wilayah asing bagi negara asal tersebut. Sebagai contoh, Ronald J. Horvath menjelaskan "Kolonialisme" dan "Imperialisme" sebagai "dominasi antarkelompok" yang di dalamnya satu kelompok mendominasi kelompok yang berbeda. Namun, Kolonialisme didefinisikannya sebagai "dominasi antarkelompok yang di dalamnya para pemukim dalam jumlah yang signifikan bermigrasi secara permanen ke koloni dari wilayah asal penjajah tersebut" ("Intergroup domination in which settlers in significant number migrate permanently to the colony from the colonizing power").${ }^{19}$ Sementara itu, "Imperialisme" didefinisikan sebagai "dominasi antar kelompok yang di dalamnya hanya terdapat sedikit perpindahan, jika ada, pemukim tetap dari negara penjajah ke daerah jajahan" ("Intergroup domination in which few, if any, permanent settlers from the imperial homeland migrate to the colony"). Definisi ini selaras dengan pemahaman Kohn dan Reddy, penulis entri mengenai Kolonialisme di dalam Stanford Encyclopedia of Philosophy, yang berpandangan bahwa Kolonialisme biasanya

\footnotetext{
${ }^{16}$ Margaret Kohn dan Kavita Reddy, "Colonialism," dalam The Stanford Encyclopedia of Philosophy, 2017,

https://plato.stanford.edu/archives/fall2017/entries/col onialism/.

${ }^{17}$ Steinmetz, "The Sociology of Empires, Colonies, and Postcolonialism," 79.

${ }^{18}$ Kohn dan Reddy, "Colonialism."

${ }^{19}$ Ronald J. Horvath, "A Definition of Colonialism," Current Anthropology 13, no. 1 (1972): 50, https://doi.org/10.1086/201248.
}

ditandai dengan perpindahan populasi ke wilayah baru (yang dijajah) dengan tetap mempertahankan keanggotaan dan kesetiaan politik penduduk yang dipindahkan tersebut pada negara asalnya. Sementara itu, Imperialisme merujuk kepada cara sebuah negara untuk mengendalikan dan menguasai negara lain, baik melalui pemukiman (settlement), pengambilalihan kedaulatan, maupun mekanisme penguasaan yang bersifat tidak langsung. ${ }^{20}$

Pembedaan Kolonialisme dan Imperialisme dengan menggunakan akar etimologisnya ini memberikan penekanan pada keberadaan atau besar kecilnya perpindahan penduduk dari negara asal ke wilayah baru yang dijajah. Disadari atau tidak, pembedaan tersebut menekankan pengalaman dari negara penjajah, yang menjadi pengirim penduduk ke wilayah baru sekaligus harus menjamin keamanan dari penduduk koloni yang berada di wilayah yang dijajahnya tersebut. Bagi negara atau penduduk yang terjajah, banyak atau sedikitnya orang asing yang tinggal secara permanen di wilayahnya bukan pengalaman yang utama. Yang lebih penting adalah penguasaan dari negara asing terhadap penduduk dan wilayah tersebut.

Barangkali karena inilah, para peneliti yang melihat pengalaman negara-negara terjajah, seperti para spesialis kajian wilayah Asia Tenggara, memiliki pandangan berbeda. Robert Van Niel dari University of Hawaai, yang sering mengkaji Asia Tenggara termasuk Indonesia, tidak melihat bahwa keberadaan pemukiman dari penduduk negara penjajah di wilayah asing sebagai penanda yang paling penting dalam mendefinisikan kolonialisme. Ia mendefinisikan kolonialisme sebagai "dominasi dari negara yang kuat terhadap masyarakat yang lebih lemah, yang dikuasai dan diperlakukan tidak seperti penduduk di negara asal (yaitu negara yang mendominasi

${ }^{20}$ Kohn dan Reddy, "Colonialism." 
tersebut). ${ }^{21}$ Ia menekankan pengalaman si Terjajah bahwa Kolonialisme ditandai dengan perlakuan diskriminatif dari kekuatan penjajah yang bisa mengatur berbagai aspek kehidupannya. Definisi ini senada dengan pengertian yang diajukan oleh George Steinmetz, yang mendefinisikan Kolonialisme sebagai "Penaklukan masyarakat asing yang diikuti dengan penciptaan sistem pengelolaan yang dikendalikan oleh negara penakluk dan dirancang untuk memerintah penduduk tempatan wilayah yang ditaklukkan". ${ }^{22}$ Pada saat yang bersamaan, Steinmetz mendefinisikan Imperialisme sebagai sesuatu yang lebih umum, yaitu "penguasaan politik atas tanah-tanah asing". ${ }^{23}$ Tidak seperti Kolonialisme yang ditandai dengan keberadaan sebuah pemerintahan di wilayah jajahan yang dikendalikan oleh si Penjajah untuk mengatur si Terjajah, kendali politik dalam Imperialisme tidak selalu mempersyaratkan penaklukan, pendudukan, atau pemerintahan yang berkelanjutan dari kekuatan asing. ${ }^{24}$

Dengan demikian, secara umum, kita dapat melihat bahwa sebagian cendekiawan melihat bahwa Imperialisme adalah konsep yang lebih umum dari Kolonialisme. Kalau diumpamakan, Imperialisme adalah Operating System dari sebuah komputer, sementara Kolonialisme adalah Software yang mengerjakan tugas yang dikehendaki oleh penggunanya. Namun, seberapa umum Imperialisme ini juga seringkali mengundang perdebatan, karena ada yang menggunakannya untuk menggambarkan kebijakan luar negeri Amerika Serikat kontemporer, yang tidak menetapkan sebuah pemerintahan langsung di bawah pemerintah Amerika Serikat namun seringkali mencampuri politik suatu negara untuk

\footnotetext{
${ }^{21}$ Robert Van Niel, "Colonialism Revisited: Recent Historiography," Journal of World History 1, no. 1 (1990): 109.

${ }^{22}$ Steinmetz, "The Sociology of Empires, Colonies, and Postcolonialism," 79.

${ }^{23}$ Steinmetz, 79.

${ }^{24}$ Steinmetz, 79.
}

menentukan siapa yang berkuasa, yang biasanya lebih bersahabat dengan kekuatan adidaya tersebut.

Hubungan umum-khusus ini sendiri juga masih memicu perdebatan lanjutan. Sebagian cendekiawan memandang bahwa Imperialisme adalah penguasaan politik terhadap entitas asing yang bisa terjadi sepanjang sejarah, sementara Kolonialisme adalah bentuk pengorganisasiannya yang lebih spesifik, yang seringkali diidentikkan dengan pengendalian daerah-daerah jajahan Eropa sejak akhir abad 15 hingga awal abad 20. Dengan demikian, Imperialisme bersifat trans-historikal, sementara Kolonialisme menempati satu fase sejarah tertentu.

Tidak semuanya menyepakati pandangan bahwa Imperialisme bersifat trans-historikal ini. Para teoretisi Imperialisme yang mengembangkan gagasan Marx, seperti Hobson, Vladimir Lenin, atau Rosa Luxemburg, melihat Imperialisme sebagai sebuah fase spesifik dalam sejarah perkembangan kapitalisme. "Imperialisme," menurut Lenin, adalah "tahap terakhir dari kapitalisme". ${ }^{25}$ Menulis pada tahun 1916, Lenin dipengaruhi oleh gagasan Hobson yang menuliskan pada tahun 1902 bahwa Imperialisme adalah upaya agresif dari kapital untuk mencari pasar dan investasi di luar negeri dalam periode underconsumption yang merupakan konsekuensi dari ketegangan internal di dalam sistem kapitalis itu sendiri. ${ }^{26}$ Senada dengan pandangan Hobson dan Lenin tersebut, Rosa Luxemburg juga melihat bahwa Imperialisme adalah tahap akhir dari

\footnotetext{
25 Vladimir Ilyich Lenin, "Imperialism, the Highest Stage of Capitalism: A Popular Outline," in Selected Works (Moscow: Progress Publisher, 1963), https://www.marxists.org/archive/lenin/works/1916/i mp-hsc/.

${ }^{26}$ A. M. Eckstein, "Is There a 'Hobson-Lenin Thesis' on Late Nineteenth-Century Colonial Expansion?," The Economic History Review 44, no. 2 (1991): 297, https://doi.org/10.2307/2598298; Steinmetz, "The Sociology of Empires, Colonies, and Postcolonialism."
} 
asimilasi masyarakat pra-kapitalis ke dalam kapitalisme. ${ }^{27}$

Jembatan bagi kedua definisi mengenai imperialisme yang bersifat trans-historikal dan yang meletakkannya sebagai fase dalam perkembangan historis kapitalisme dapat kita temukan dalam pidato pembelaan Soekarno saat disidang di Landraad Bandung atas tuduhan merencanakan makar terhadap pemerintah kolonial pada tahun 1930. Alihalih meminta belas kasihan dari pemerintah kolonial, tokoh pergerakan nasional itu malah berpidato panjang lebar menjelaskan keburukan-keburukan yang ditimbulkan oleh Kolonialisme-Imperialisme.

Ia mengawalinya dengan menjelaskan mengenai Imperialisme, yang dibedakannya menjadi dua: Imperialisme Tua dan Imperialisme Modern. Imperialisme Tua adalah Imperialisme yang terjadi sejak masa kuno, sebelum paruh kedua abad ke-19. Imperialisme Modern, sementara itu, adalah anak kandung dari Kapitalisme. Dengan demikian, Soekarno tidak melihat adanya pertentangan dari pemahaman mengenai Imperialisme yang trans-historikal dan yang melihatnya sebagai suatu fase mutakhir dalam kapitalisme. Ketika kita melihat Imperialisme sebagai sesuatu yang transhistorikal, kita sedang membicarakan Imperialisme secara umum, termasuk yang terjadi sejak zaman -meminjam istilah Soekarno- "Garuda Romein terbang kemanamana menakluk-naklukkan negeri-negeri sekelilingnya dan di luarnya LautanTengah." Sementara itu, pendefinisian yang tidak melihat Imperialisme sebagai sesuatu yang trans-historikal sebenarnya sedang membicarakan satu wujud khusus dari Imperialisme, yaitu Imperialisme Modern.

Dalam kerangka pikir yang demikian, penulis menemukan bahwa definisi yang diajukan oleh Gottheil dapat menjadi titik awal yang memberikan petunjuk cukup terang. Gottheil mengakui bahwa

\footnotetext{
${ }^{27}$ George Lee, "Rosa Luxemburg and the Impact of Imperialism," The Economic Journal 81, no. 324 (1971): 850.
}

Kolonialisme adalah sebuah konglomerasi dari relasi penjajah-terjajah yang meliputi beragam dimensi dan dengan demikian dapat bersifat transhistorikal. Namun, ia juga sekaligus mengajak kita mendefinisikannya dengan melihat atribut yang paling penting: ekonomi. Ia mendefinisikan Kolonialisme sebagai "serangkaian struktur yang dipaksakan untuk diterapkan pada sebuah bangsa oleh bangsa yang lain untuk mempengaruhi distribusi internasional pendapatan dan kekayaan" ("a set if structures that are imposed upon a nation by another to affect international distributions of income and wealth"). ${ }^{28}$ Yang menjadi penanda Kolonialisme di semua mekanisme bukanlah bentuk formalnya yang bisa beragam, namun "pemaksaaan hak-hak istimewa" ("imposition of privilege"). ${ }^{29}$ Keberadaan perusahaan dan modal asing belum tentu kolonial jika aturan ditetapkan oleh otoritas lokal dan penduduk lokal memiliki kemerdekaan dalam mengatur apa yang mereka produksi atau dengan siapa dia berdagang. Kolonialisme terjadi ketika perusahaan asing tersebut menjadi pihak yang menentukan aturan tentang apa yang harus diproduksi atau dengan siapa penduduk setempat boleh berdagang, sebagaimana dalam kasus VOC di Nusantara. Gottheil mengatakan bahwa Kolonialisme ditandai dengan "ketidakmampuan mereka yang dijajah untuk menentukan aturan-aturan yang mengatur lingkungan ekonomi mereka ("the inability of those people affected to exercise control over the rules governing their economic environment"). ${ }^{30}$

Nasionalis India, Bipan Chandra, juga mengutarakan hal yang serupa namun lebih spesifik dan ideologis. Ia menyebut Kolonialisme sebagai sebuah "sistem yang utuh dan terstruktur dengan rapi, sebuah formasi sosial yang khas...yang di dalamnya kendali dasar dari ekonomi dan masyarakat

\footnotetext{
28 Fred M. Gottheil, "On an Economic Theory of Colonialism," Journal of Economic Issues 11, no. 1 (1977): 85.

${ }^{29}$ Gottheil, 85-86.

${ }^{30}$ Gottheil, 86.
} 
berada di tangan kelas kapitalis asing yang bekerja di wilayah koloni (atau semi-koloni) melalui struktur ekonomi, social, politik dan intelektual yang bentuknya bisa beragam sesuai dengan perubahan kondisi dari perkembangan sejarah kapitalisme sebagai sebuah sistem yang mendunia" ("is a wellstructured 'whole', a distinct social formation...in which the basic control of the economy and society is in the hands of a foreign capitalist class which functions in the colony (or semi-colony) through a dependent and subservient economic social, political, and intellectual structure whose forms can vary with changing conditions of the historical development of capitalism as a worldwide system"). Ia menekankan bahwa struktur yang dibentuk oleh Kolonialisme tidak hanya ekonomi. Untuk mengatur struktur ekonomi, Kolonialisme juga memaksakan seperangkat pola hubungan sosial, politik, dan bahkan intelektual.

Definisi Kolonialisme ini selaras dengan definisi Soekarno tentang Imperialisme. Dalam pidato Indonesia Menggugat, ia mengatakan: "Tetapi arti perkataan imperialisme? Imperialisme juga suatu faham, imperialisme juga suatu begrip. Ia bukan sebagai yang dituduhkan pada kami itu. Ia bukan ambtenaar B.B., bukan pemerintah, bukan gezag, bukan badan apapun jua. Ia adalah suatu nafsu, suatu stelsel menguasai atau mempengaruhi ekonomi bangsa lain atau negeri bangsa lain, - suatu stelsel overheerschen atau beheerschen economie atau negeri bangsa lain." Kalau Kolonialisme adalah sistemnya, Imperialisme adalah nafsu, faham, atau ideologi untuk menguasai dan mempengaruhi ekonomi bangsa atau negeri bangsa lain. Hasrat-hasat inilah yang kemudian menjelma ke dalam sistem kolonialisme. Pasangan Dwitunggal Soekarno, Mohammad Hatta, mengatakan dengan lebih terang benderang dalam kuliahnya di depan International Holiday Course yang diselenggarakan oleh Liga Perempuan Internasional untuk Perdamaian dan Kebebasan pada tahun 1927, bahwa kolonisasi seharusnya didefinisikan sebagai berikut: "penerapan hasrat-hasrat untuk merampok dan kerakusan negeri-negeri yang lebih kuat secara material untuk dapat memuaskan kepentingan ekonomi dan komersial mereka atas tanggungan negerinegeri yang lebih lemah.". ${ }^{31}$

Definisi dari Gottheil, Bipan Chandra, Soekarno, dan Hatta ini, meskipun cukup umum, memberikan kita petunjuk untuk melihat elemen paling penting dari Kolonialisme-Imperialisme, $\quad$ yaitu pembentukan dan pemaksaan penerapan suatu struktur tertentu oleh kekuatan asing demi kepentingan kekuatan asing tersebut.

Struktur Kolonialisme membentuk secara paksa pola hubungan antara Penjajah dengan yang Dijajah. Kolonialisme menentukan apa yang dihasilkan, dibangun, dan diekspor oleh masyarakat yang dijajah, dan tentu saja apa yang tidak boleh dihasilkan dan dibangun oleh masyarakat tersebut. Dengan kata lain, Kolonialisme membentuk pola interaksi antara negara jajahan dengan penjajahnya sekaligus dengan sistem Ekonomi Politik Global dengan menetapkan suatu posisi bagi negara jajahan tersebut di dalam pembagian kerja internasional ("International Division of Labour").

Dengan memahami Kolonialisme sebagai "serangkaian struktur yang dipaksakan untuk diterapkan pada sebuah bangsa oleh bangsa yang lain untuk mempengaruhi distribusi internasional pendapatan dan kekayaan,” secara kronologis kita dapat memberikan titik start bagi Kolonialisme-Imperialisme di Indonesia sejak tahun 1600an, yaitu ketika VOC dengan beragam hak istimewanya kemudian bisa memaksakan struktur ekonomi tertentu yang dikehendakinya pada berbagai penduduk lokal di Nusantara, bukan hanya ketika Pemerintah Belanda secara resmi membangun Pemerintah Kolonial di HindiaBelanda setelah VOC bangkrut. Tentu saja,

\footnotetext{
31 Hatta, Mohammad Hatta: Politik, Kebangsaan, Ekonomi (1926-1977), 35.
} 
kemampuan memaksakan struktur ekonomi tertentu ini mengalami gradasi baik secara spasial maupun temporal sepanjang periode Kolonialisme-Imperialisme. Kemampuan VOC memaksakan struktur dan pola relasi di dalamnya jelas tidak semenyeluruh Pemerintah Kolonial Belanda yang mulai berkuasa sejak awal abad 19. Tidak hanya itu, bahkan Pemerintah Kolonial Belanda pun tidak pernah secara merata dan total menguasa seluruh wilayah yang kemudian menjadi Indonesia. "Indonesia pernah dijajah sepanjang 350 tahun" yang sering diungkapkan oleh Bung Karno memang bukan pernyataan yang didasarkan pada penelitian formal sejarah, tapi interpretasi ekonomi politik internasional terhadap transformasi struktural yang dipaksakan melalui penjajahan sekaligus sebagai sebuah deklarasi untuk membangkitkan perlawanan terhadap proses yang menguntungkan segelintir orang di metropolis dunia tapi memiskinkan orang-orang di tanah jajahan atau apa yang disebut Soekarno sebagai "kaum marhaen."

\section{Penjajahan Sebagai Proses, Bukan Event}

Dengan melihat penjajahan sebagai serangkaian "proses" dan bukan hanya "event," maka kedatangan VOC pada tahun 1600 -an yang memulai proses perubahan struktur ekonomi politik di wilayah yang kemudian dikenal sebagai Indonesia (colonial dispossession) harus dilihat sebagai satu kesatuan yang tidak terpisahkan dari proyek pembangunan negara kolonial dan perluasannya setelah keruntuhan VOC. Dalam konteks inilah saya kira Soekarno repot-repot menjelaskan mengenai Kolonialisme Tua dan Kolonialisme Modern dalam pidato yang kemudian dikenal sebagai Indonesia Menggugat. Dalam konteks ini pulalah Hatta berulangkali menuliskan sejarah kolonialisme dan kapitalisme untuk menjelaskan persoalan Indonesia. Dalam terang ekonomi politik internasional ini, penjajahan sudah dimulai sejak VOC mengubah pola perdagangan internasional di nusantara melalui penggunaan kekerasan maupun dengan perjanjian-perjanjian yang dipaksakan pada penguasa-penguasa setempat. Perjanjian-perjanjian tersebut bisa jadi menyatakan secara resmi bahwa penguasa-penguasa setempat tersebut berdaulat secara politik, namun interaksi ekonomi mereka diatur oleh perjanjianperjanjian tersebut untuk melayani kepentingan metropolis di Eropa. Dalam hal ini, perjanjian-perjanjian itu bukan menunjukkan kesetaraan antar pihak meskipun secara formal demikian, namun lebih merupakan adalah "instrumen penahanan (instruments of containment)" untuk menundukkan orang-orang nonEropa. ${ }^{32}$

Hal ini dapat kita lihat misalnya pada perjanjian antara VOC dengan para penguasa di Kepulauan Banda. Perdagangan rempahrempah di Banda telah ramai jauh sebelum orang-orang Eropa datang. Orang-orang dari seluruh kepulauan Nusantara dan bahkan sampai ke Tiongkok hadir berdagang di tempat ini. Orang-orang Tiongkok bahkan memiliki dua jalur utama menuju kepulauan Rempah ini. Yang satu bermula dari Banda dan Ambon lalu ke Barat hingga Kepulauan Riau, lalu ke utara dan mengikuti Pesisir Champa hingga Hainan, terus hingga sampai ke Yuegang di antara Quanzhou dan Zhangzhou. Sementara jalur satunya bermula dari Ternate kemudian ke utara melewati Manila sampai di Yuegang. ${ }^{33}$

Wilayah Kepulauan Banda yang kaya ini dipimpin oleh para tokoh yang disebut "Orangkaya." Gubernur-Jenderal VOC yang menjabat pada tahun 1615-1619, Laurens Reael, menyebut bahwa Banda diperintah secara demokratis (populariter) seperti

\footnotetext{
${ }^{32}$ Martine Julia van Ittersum, "Debating Natural Law in the Banda Islands: A Case Study in Anglo-Dutch Imperial Competition in the East Indies, 1609-1621," History of European Ideas 42, no. 4 (2016): 463, https://doi.org/10.1080/01916599.2015.1101216.

${ }^{33}$ Guanmian Xu, "Junks to Mare Clausum: ChinaMaluku Connections in the Spice Wars, 1607-1622," Itinerario 44, no. 1 (2020): 203-4, https://doi.org/10.1017/S016511531900055X.
} 
layaknya republik. ${ }^{34}$ Mereka berdagang dengan semua orang dan mencoba menjaga kemerdekaannya dengan membangun perimbangan kekuatan antara orang-orang asing. Pada saat orang-orang Spanyol dan Belanda datang, situasi menjadi rumit. Keduanya bersaing dengan keras sampai seorang pedagang yang berasal dari Tiongkok berspekulasi bahwa cengkeh digunakan oleh kedua kelompok orang-orang barbar ini untuk memperkuat energi kedigdayaan raja mereka (wangqi 王氣). ${ }^{35}$

Saat orang-orang Eropa, termasuk VOC, datang dan mengatakan ingin berdagang, para pemimpin Banda menerima dengan tangan terbuka. Mereka memperlakukan VOC sama seperti pedagang lain dari seluruh dunia. Kalau Anda bisa menjual barang yang kami butuhkan, kami bisa menjual rempah-rempah pada Anda. Untuk menjaga kondisi tersebut, para pemimpin Banda juga menerima kehadiran para pedagang lain dari Eropa yang merupakan rival VOC, untuk menciptakan sebuah perimbangan kekuatan yang menjaga independensi mereka. ${ }^{36}$ Namun, VOC tidak puas dengan perdagangan yang terbuka (bertentangan dengan posisi Grotius yang memperjuangkan laut bebas pada saat Portugis berkuasa untuk kepentingan Belanda). VOC rakus dan ingin menguasai semuanya.

Kompetisi yang semakin meningkat antara kekuatan-kekuatan Eropa kemudian membuat VOC semakin agresif memaksakan perjanjian dengan para pemimpin setempat dengan alasan melindungi mereka dari kekuatan asing lain. Kurang lebih seperti preman di pasar yang memaksakan perjanjian uang keamanan. Kesepakatankesepakatan ini digunakan untuk

\footnotetext{
${ }^{34}$ van Ittersum, "Debating Natural Law in the Banda Islands: A Case Study in Anglo-Dutch Imperial Competition in the East Indies, 1609-1621," 491.

$35 \mathrm{Xu}$, "Junks to Mare Clausum: China-Maluku Connections in the Spice Wars, 1607-1622," 209.

${ }^{36}$ van Ittersum, "Debating Natural Law in the Banda Islands: A Case Study in Anglo-Dutch Imperial Competition in the East Indies, 1609-1621," 491.
}

memperkuat benteng-benteng dan posisi militer VOC di Banda, yang tentu saja membuat pemimpin setempat merasa dirampok kedaulatannya. Pada tahun 1602, Wolfert Hermanszoon menyodorkan perjanjian dalam Bahasa Belanda yang tidak dimengerti oleh para pemimpin setempat. Isinya adalah penyerahan monopoli perdagangan pala. Sebagian pemimpin setempat memberikan tanda tangan karena diancam, sementara yang lain tidak memberikan tanda tangan. Dengan dasar perjanjian yang dibuat dalam tekanan inilah pada tahun 1609 Pieter Verhoeven (atau Peter Verhoef) kemudian menuduh orangorang Banda mengkhianati perjanjian, karena mereka masih berdagang dengan yang lain. Verhoef memaksa mendirikan benteng dengan penuh arogansi dan orang-orang Banda yang merasa dilecehkan kemudian melawan. Verhoef tewas pada bulan Mei 1609. ${ }^{37}$ VOC kemudian menggunakan terbunuhnya Verhoef untuk melancarkan pembalasan brutal yang berujung pada keterpaksaan para Orangkaya Banda untuk menyepakati pemberian monopoli perdagangan pala pada VOC. Belanda pun meneruskan pembuatan Benteng di Neira (1609), Pulo Way (1616) dan Lontor $(1621) .^{38}$

Namun, memonopoli perdagangan pala di Maluku yang terdiri dari banyak pulau merupakan misi yang sulit. Orang-orang Banda mencoba melawan dengan mencoba menjalin kerjasama dengan EIC, serikat dagang Inggris, yang juga beroperasi di Maluku. J.P. Coen, yang kemudian diangkat menjadi Gubernur Jenderal VOC, pada 10 November 1614 menuliskan surat ke para pemilik saham VOC di Belanda bahwa "kalau orang-orang asing dibiarkan berdagang, tuan-tuan tidak akan menemui

\footnotetext{
37 Stephen R. Bown, Merchant Kings: When Companies Ruled the World, 1600-1900 (New York: Thomas Dunne Books, St. Martin's Press, 2009), 914.

${ }^{38}$ van Ittersum, "Debating Natural Law in the Banda Islands: A Case Study in Anglo-Dutch Imperial Competition in the East Indies, 1609-1621," 460.
} 
apa-apa kecuali biaya perang". ${ }^{39}$ Penting untuk diingat bahwa Coen saat itu masih seorang pegawai VOC yang ditempatkan di Banten, ribuan kilometer dari Banda.

Pada 25 Oktober 1617, Tuan Tuan yang Tujuhbelas menunjuk Coen menjadi Gubernur Jenderal VOC dengan tugas untuk segera bertindak tegas pada para pedagang asing di kepulauan rempah-rempah. VOC juga mengeluarkan "Instructie voor den Gouverneur en de Raden van Indië" (Instruksi untuk Gubernur dan Dewan Hinda) yang menggariskan kebijakan untuk mengusir pedagang asing dari Kepulauan Rempah, termasuk penggunaan penggunaan kekuatan militer. ${ }^{40}$ Setelah beberapa tahun menjabat, Coen kehilangan kesabaran. Ia berpendapat bahwa hal tersebut tidak akan terjadi jika warga asli Banda masih dibiarkan bebas. Pandangan Coen ini kemudian membuat VOC membawa pasukan besar Belanda, termasuk seratusan ronin dari Jepang, untuk menyerbu dan menguasai Banda sepenuhnya pada tahun 1621. Cerita selanjutnya sudah masyhur: Genosida Banda 1621. Dari sekitar 15.000 penduduknya, hanya ratusan atau sekitar seribu yang dibiarkan hidup. Yang lain dibantai dengan keji. Sebagian dikirimkan ke Batavia sebagai budak. $^{41}$

Dalam konteks yang demikian, kita perlu memahami penjajahan bukan sebagai "event," tetapi sebagai proses. Perjanjian VOC dengan Orangkaya Banda bukanlah "event" yang bisa dilihat terpisah dari fenomena yang lebih belakangan seperti pembangunan negara kolonial Hindia Belanda yang baru dimulai pada abad 19. Gurminder K. Bhambra memberikan kita kerangka untuk memahami perkembangan ini sebagai proses berkelanjutan yang menautkan perkembangan kapitalisme dan kolonialisme sekaligus. Penjajahan, menurut

$39 \mathrm{Xu}$, "Junks to Mare Clausum: China-Maluku Connections in the Spice Wars, 1607-1622," 211.

${ }^{40} \mathrm{Xu}, 213$.

${ }^{41}$ van Ittersum, "Debating Natural Law in the Banda Islands: A Case Study in Anglo-Dutch Imperial Competition in the East Indies, 1609-1621," 463-64.
Bhambra, adalah proses struktural yang di dalamnya masyarakat kapitalis muncul dengan ditopang oleh perampasan tanah. Mengulang apa yang disampaikan oleh Nichols, perampasan kolonial merupakan proses historis dalam pembentukan "hak milik" di dunia kolonial, yang menjadi konteks bagi tahap awal kemunculan kapitalisme di Eropa. ${ }^{42}$ Tanpa relasi penjajahan ini, kapitalisme di Eropa tidak bisa tumbuh. Pada tahap awal perkembangan kapitalisme dan kolonialisme, "kapitalisme merkantilis" atau "kolonialisme melalui kepemilikan pribadi" ini dijalankan oleh perusahaan-perusahaan yang diberikan piagam oleh kerajaan-kerajaan di Eropa, seperti VOC atau EIC. Pada tahap selanjutnya, kolonialisme berkembang menjadi proyek nasional, ketika negaranegara Eropa yang semakin mapan sebagai negara-bangsa (nation-state) berupaya mendomestikasi aktivitas eksternal dari perusahaan-perusahaan swasta tersebut melalui kendali imperial langsung. Bhambra menyebutnya sebagai "kolonialisme yang dikelola negara" ("state managed colonialism"). ${ }^{43}$

\section{Kesimpulan}

Melalui pembahasan di atas, kita dapat memahami mengapa para pemimpin pergerakan nasional Indonesia, yang membaca fenomena penjajahan melalui kacamata Ekonomi Politik Internasional, banyak yang mempopulerkan pandangan bahwa Indonesia dijajah lebih dari 300 tahun. Mereka tidak berupaya melanggengkan mitos Pax Nederlandica atau hanya membajak mitos untuk membangkitkan nasionalisme, namun memahami penjajahan sebagai proses transformasi struktural yang berkelanjutan.

42 Gurminder K. Bhambra, "Colonial Global Economy: Towards a Theoretical Reorientation of Political Economy," Review of International Political Economy 0, no. 0 (2020): 4, https://doi.org/10.1080/09692290.2020.1830831.

${ }^{43}$ Bhambra, 5-9. 
Shofwan Al Banna Choiruzzad | Indonesia Dijajah Lebih dari 300 Tahun?

Memahami Penjajahan sebagai Proses Transformasi Struktural

Hal ini bukan berarti bahwa penafsiran historis yang diajukan oleh Resink dan para sejarawan lainnya tidak valid. Namun, penulis berpandangan bahwa interpretasi yang lebih luas terhadap "penjajahan," dengan tidak hanya melihat pengakuan formal tentang kedaulatan yang terdapat dalam perjanjian (seperti dicontohkan dalam kasus perjanjian antara VOC dengan para penguasa setempat di Banda), dapat membantu kita memahami klaim tersebut dengan lebih arif dan tidak serta merta menyalahkannya sebagai kebohongan.

Pertanyaan lanjutan yang kemudian menjadi penting untuk terus kita tanyakan kemudian jika kita menerima pemahaman bahwa penjajahan adalah sebuah proses transformasi struktural yang berkelanjutan adalah apakah benar penjajahan tersebut terhenti setelah Indonesia mendeklarasikan kemerdekaannya? Tidak heran, Soekarno terobsesi dengan gagasan Neo-kolonialisme dan Neo-Imperialisme. Hatta, sementara itu, juga mendorong penataan ulang struktur ekonomi politik nasional melalui gagasan koperasi. Namun, seperti terjadi di hampir semua negara bekas jajahan, upaya-upaya tersebut tidak pernah benar-benar tuntas. 
Shofwan Al Banna Choiruzzad | Indonesia Dijajah Lebih dari 300 Tahun?

Memahami Penjajahan sebagai Proses Transformasi Struktural

\section{DAFTAR PUSTAKA}

Absiroh, Ulil. "Understanding of History 350 Years Indonesia Colonized By Dutch." Jurnal Online Mahasiswa (JOM) Fakultas Keguruan Dan Ilmu Pendidikan (FKIP) Universitas Riau 1 (2017): 1-15. https://www.neliti.com/publications/205480/sejarah-pemahaman350-tahun-indonesia-dijajah-belanda.

Bhambra, Gurminder K. "Colonial Global Economy: Towards a Theoretical Reorientation of Political Economy." Review of International Political Economy 0, no. 0 (2020): 1-16. https://doi.org/10.1080/09692290.2020.1830831.

Bown, Stephen R. Merchant Kings: When Companies Ruled the World, 1600-1900. New York: Thomas Dunne Books, St. Martin's Press, 2009.

Bryman, Alan. Social Research Methods. 4th editio. Oxford: Oxford University Press, 2012.

Eckstein, A. M. "Is There a 'Hobson-Lenin Thesis' on Late Nineteenth-Century Colonial Expansion?" The Economic History Review 44, no. 2 (1991): 297. https://doi.org/10.2307/2598298.

Gonggong, Anhar. Muhammad Husni Thamrin. Jakarta: Departemen Pendidikan dan Kebudayaan, 1985.

Gottheil, Fred M. "On an Economic Theory of Colonialism." Journal of Economic Issues 11, no. 1 (1977): 83-102.

Hatta, Mohammad. Kumpulan Karangan. Jakarta, Amsterdam, Surabaya: Penerbitan dan Balai Buku Indonesia, 1953.

—. Mohammad Hatta: Politik, Kebangsaan, Ekonomi (1926-1977). Jakarta: Penerbit Buku Kompas, 2015.

Horvath, Ronald J. “A Definition of Colonialism." Current Anthropology 13, no. 1 (1972): 45-57. https://doi.org/10.1086/201248.

Ittersum, Martine Julia van. "Debating Natural Law in the Banda Islands: A Case Study in Anglo-Dutch Imperial Competition in the East Indies, 1609-1621." History of European Ideas 42, no. 4 (2016): 459-501. https://doi.org/10.1080/01916599.2015.1101216.

Klotz, Audie, dan Deepa Prakash (Eds.). Qualitative Methods in International Relations: A Pluralist Guide. Hampshire and New York: Palgrave McMillan, 2008.

Kohn, Margaret, dan Kavita Reddy. "Colonialism." In The Stanford Encyclopedia of Philosophy, 2017. https://plato.stanford.edu/archives/fall2017/entries/colonialism/.

“Koloniaal Onderwijsstelsel Dan Nasibnja Anak Djadjahan." Fikiran Ra'jat, December 1932.

Lee, George. "Rosa Luxemburg and the Impact of Imperialism." The Economic Journal 81, no. 324 (1971): 847-62.

Lenin, Vladimir Ilyich. "Imperialism, the Highest Stage of Capitalism: A Popular Outline." In Selected Works. Moscow: Progress Publisher, 1963. https://www.marxists.org/archive/lenin/works/1916/imp-hsc/.

Niel, Robert Van. "Colonialism Revisited: Recent Historiography." Journal of World History 1, no. 1 (1990): 109-24.

Resink, Gertrudes Johannes. Bukan 350 Tahun Dijajah. Depok: Komunitas Bambu, 2013.

Soekarno. Di Bawah Bendera Revolusi (Jilid Pertama). Jakarta: Yayasan Bung Karno, 2005.

Steinmetz, George. "The Sociology of Empires, Colonies, and Postcolonialism." Annual Review of Sociology 40, no. 1 (2014): 77-103. https://doi.org/10.1146/annurev-soc071913-043131.

Tirta, Tyson. "Bagaimana G.J. Resink Membongkar Mitos 350 Tahun Penjajahan Belanda." Tirto, 2020. https://tirto.id/bagaimana-gj-resink-membongkar-mitos-350-tahunpenjajahan-belanda-f3sv.

$\mathrm{Xu}$, Guanmian. "Junks to Mare Clausum: China-Maluku Connections in the Spice Wars, 
Shofwan Al Banna Choiruzzad | Indonesia Dijajah Lebih dari 300 Tahun? Memahami Penjajahan sebagai Proses Transformasi Struktural

1607-1622." Itinerario 44, no. 1 (2020): 196-225. https://doi.org/10.1017/S016511531900055X. 
Shofwan Al Banna Choiruzzad | Indonesia Dijajah Lebih dari 300 Tahun?

Memahami Penjajahan sebagai Proses Transformasi Struktural

\section{BIOGRAFI}

Shofwan Al Banna Choiruzzad adalah dosen di Departemen Ilmu Hubungan Internasional, Fakultas Ilmu Sosial dan Ilmu Politik, Universitas Indonesia. Shofwan juga bertugas sebagai Sekretaris Eksekutif ASEAN Study Center di Universitas Indonesia. Minat penelitiannya meliputi pertautan antara berbagai dimensi (sistem internasional, ekonomi politik global, dan sistem ekologis), skala (global, regional, nasional, dan local), dan ruang temporal (masa lalu, masa kini, masa depan). Tulisannya telah dipublikasikan di berbagai jurnal nasional dan internasional, seperti Asia Europe Journal, Asian Perspectives, Asian Politics and Policy, Contemporary Southeast Asia, Forest Policy and Economics, Indonesia, Africa In Fact, Global, dan IKAT. Pada tahun 2009, esainya mengenai Revival of Economic and Political Boundaries mendapatkan St.Gallen Wings of Excellence Award. 